\title{
Pathogenicity Groups of Bean Common Mosaic Virus Isolates in Kenya
}

Michael E. Omunyin, Kenya Agricultural Research Institute (KARI), National Horticultural Research Center, P.O. Box 220, Thika, Kenya; E. M. Gathuru, Department of Biological Sciences, Egerton University, P.O. Box 536, Njoro, Kenya; and D. M. Mukunya, Crop Science Department, University of Nairobi, P.O. Box 30197, Nairobi, Kenya

\begin{abstract}
Omunyin, M. E., Gathuru, E. M., and Mukunya, D. M. 1995. Pathogenicity groups of bean common mosaic virus isolates in Kenya. Plant Dis. 79:985-989.

Studies were conducted to determine the geographic distribution of bean common mosaic virus (BCMV) in areas of Kenya with high intensity of bean (Phaseolus vulgaris L.) cultivation and to identify virus strains by using differential $P$. vulgaris cultivars. The incidence of BCMV in farmers' fields in Central, Rift Valley, Eastern, Western, and the lake basin areas of Kenya varied from 0 to $60 \%$. Disease prevalence was associated with the distribution pattern of the aphid vector, Aphis fabae, and seed selection practices by farmers. Fourteen virus isolates from infected beans were differentiated into four BCMV pathogenicity groups (PGs). These included the KN1 (PG VI) and KN3 (PG V) groups as well as two potentially new groups. The majority of isolates were the necrosis-inducing type. Implications are discussed for bean improvement research in Kenya.
\end{abstract}

Additional keywords: black root, cropping pattern, potyvirus, seed management

Bean common mosaic potyvirus (BCMV) causes a serious disease of beans (Phaseolus vulgaris L.) that occurs worldwide. It is seedborne, and secondary spread occurs by aphid species, including Aphis fabae Scop., A. gossypii Glover, and Myzus persicae (Sulzer) (10). Symptoms of BCMV on the bean plant may include either mosaic or black root $(5,12,14)$. Black root, also known as systemic necrosis, is characterized by vascular necrosis in leaves, stems, shoot tips, and roots, followed by plant death. The black root symptoms occur in $P$. vulgaris cultivars possessing the dominant necrosis gene when infected by certain BCMV strains $(5,18)$. In contrast, mosaic develops in cultivars containing only the recessive gene and in many other susceptible Phaseolus species $(5,12)$. The basis of host-pathogen interaction and procedures for identifying BCMV strains by using specific $P$. vulgaris cultivars (genotypes) have been reported by Drijfhout $(5,6)$. Strains have been classified into seven pathogenicity groups (PGs) based

Present address of first author: Department of Plant Pathology, 351 Bessey Hall, Iowa State University, Ames 50011.

Corresponding author: Michael E. Omunyin E-mail: omunyin@iastate.edu

Accepted for publication 27 June 1995.

두 1995 The American Phytopathological Society on phenotypic reaction of differential cultivars. BCMV strains have also been divided into serogroups A (pathogroups III and VI) and B (pathogroups I, II, IV, V, and VII) $(6,19,21,22)$, which are suggested to correlate with two distinct potyviruses $(11,21)$. In Kenya, BCMV was identified first by Kulkarni (10) and then by Buruchara (4), and both mosaic and black root have been reported in farmers' fields and in Phaseolus germ-plasm collections (3,13-15; D. M. Mukunya and S. O. Keya, unpublished). These reports imply a wide distribution of the virus, but information on the prevalence of necrosis-inducing strains is lacking. We present the results of a limited survey for distribution of BCMV and identification of PGs occurring in Kenya by using the Drijfhout differentials.

\section{MATERIALS AND METHODS}

Distribution of BCMV. To assess BCMV incidence, at least six localities were visited in each of 12 districts where beans were widely grown. The survey was conducted during the long rainy season (April to June) of 1981 when beans were at flowering to podding stages. Districts represented in the survey were Kakamega and Trans Nzoia (West Kenya), Kisii and South Nyanza (the lake basin region), Nakuru (the Rift Valley), Embu, Kitui, and Machakos (Eastern region), Nyandarua, Muranga, and Kiambu (Central Kenya), and the Nairobi area. In each district, farms were systematically selected at intervals of 15 to $50 \mathrm{~km}$. Selection of farms was based on intensity of bean cultivation; the distance between farms was $15 \mathrm{~km}$ in areas with high frequency of bean farms and $>15 \mathrm{~km}$ where bean farms were few. Mosaic symptoms associated with stunting and leaf malformation were the main criteria for identification of BCMV in the field. At each farm, a sampling site was located arbitrarily. Disease incidence was assessed by counting the number of infected plants as a percentage of 200 or more (in a distance of 10 to $50 \mathrm{~m}$ ). The sampling unit depended on farm size and bean arrangement in the field; most farms were subsistence holdings of less than 3 ha where beans were grown in varied cropping systems, including monocropping and regular or row intercropping of beans with maize. Populations of the black bean aphid, A. fabae, also were recorded on at least three rows 10 to $50 \mathrm{~m}$ long (about 250 plants) selected arbitrarily. Aphid infestation was rated according to a scale showing the percentage of plants with at least one aphid, as follows: $-=0 \%$ infestation, $+=1$ to $10 \%$ infestation, $++=11$ to $20 \%$ infestation, $+++=21$ to $50 \%$ infestation, $++++=$ more than $51 \%$ infestation. Samples of plants with symptoms characteristic of BCMV $(7,12)$ were collected for study. When possible, information was collected regarding seed source and nature of seed management practices.

Virus isolates and plants. Fourteen BCMV isolates, obtained from symptomatic plants of $P$. vulgaris, had the following sites of origin: E4 and E5 (Embu, 1,460 m altitude); Nc2 and Nc4 (Chiromo, Nairobi; $1,734 \mathrm{~m}$ ); 86 and 510 (Kabete campus, Nairobi; 1,861 m); Ah (Kabete AHITI, Nairobi; $1,861 \mathrm{~m}$ ); Ny (Nyeri, 1,829 m); 4 (Gatura, Muranga; 1,969 m); 10c (Nyahururu, Nyandarua; 2,600 m) and 11a (Subukia, Nakuru; $2,134 \mathrm{~m}$ ). Three other isolates, T, K, and N, were obtained previously from K. R. Bock, then of KARI, Muguga, Nairobi, Kenya, who had collected them in farmers' fields at Thika (1,549 m), Kakamega (1,585 m), and Naivasha $(1,936 \mathrm{~m})$, respectively. These isolates had been positively identified as BCMV (3). Identity of the rest of the isolates had been verified previously (14). The host species $P$. vulgaris (cv. Long Tom), Macropithilium lathyroides, and Cassia occidentalis, used for maintaining BCMV, also were supplied by K. R. Bock. 
Phaseolus vulgaris cultivar seed, used in differentiation of BCMV isolates and obtained from E. Drijfhout (Institute of Plant Breeding, Wageningen, The Netherlands), were Stringless Green Refugee and Dubbele Witte (host resistance group 1 [HRG 1]), Imuna (HRG 2), Redlands Greenleaf B (HRG 3), Sanilac and Michelite (HRG 4), Pinto 114 (HRG 5), Monroe (HRG 6), Widusa (HRG 8), Jubila (HRG 9a), Top Crop (HRG 9b), and Amanda (HRG 10) (5). All other seed used for host range tests was obtained from the Quarantine Center, Muguga, Nairobi, Kenya. Plants and virus isolates were maintained in insect-protected glass houses at the Field Station, Kabete campus, University of Nairobi. Glass houses were maintained at a mean temperature between 20 and $28 \mathrm{C}$.

Seedling plants were grown in plastic pots (12 cm diameter) containing steamsterilized, humus-rich soil and $1 \mathrm{~g}$ of diammonium phosphate per plant. Seedlings of small-seeded plant species were raised in $6 \times 20 \times 30 \mathrm{~cm}$ trays and transplanted to the plastic pots when 8 to $12 \mathrm{~cm}$ in height. Inoculum, prepared from plant tissue collected from fields or from maintenance host plants, was used to mechanically inoculate seedlings at the primary leaf stage. Infected leaf tissues were macerated in $0.01 \mathrm{M}$ potassium phosphate buffer (1:1 $\mathrm{wt} / \mathrm{vol}, \mathrm{pH} 7.3$ ), followed by dilution in distilled water (1:10 vol/vol). Plants inoculated with individual virus isolates were separated by plastic or wire mesh screens in the glass house. Inoculations of differential bean plants were made about 12 days after seed planting. At least three plants of each differential bean variety were inoculated with each virus isolate, and one plant was left uninoculated as a control. All test plants were observed for symptom development for at least 3 weeks. To evaluate systemic infection, plants were indexed by inoculating healthy seedlings of the cultivars Long Tom, Dubbele Witte, or both.

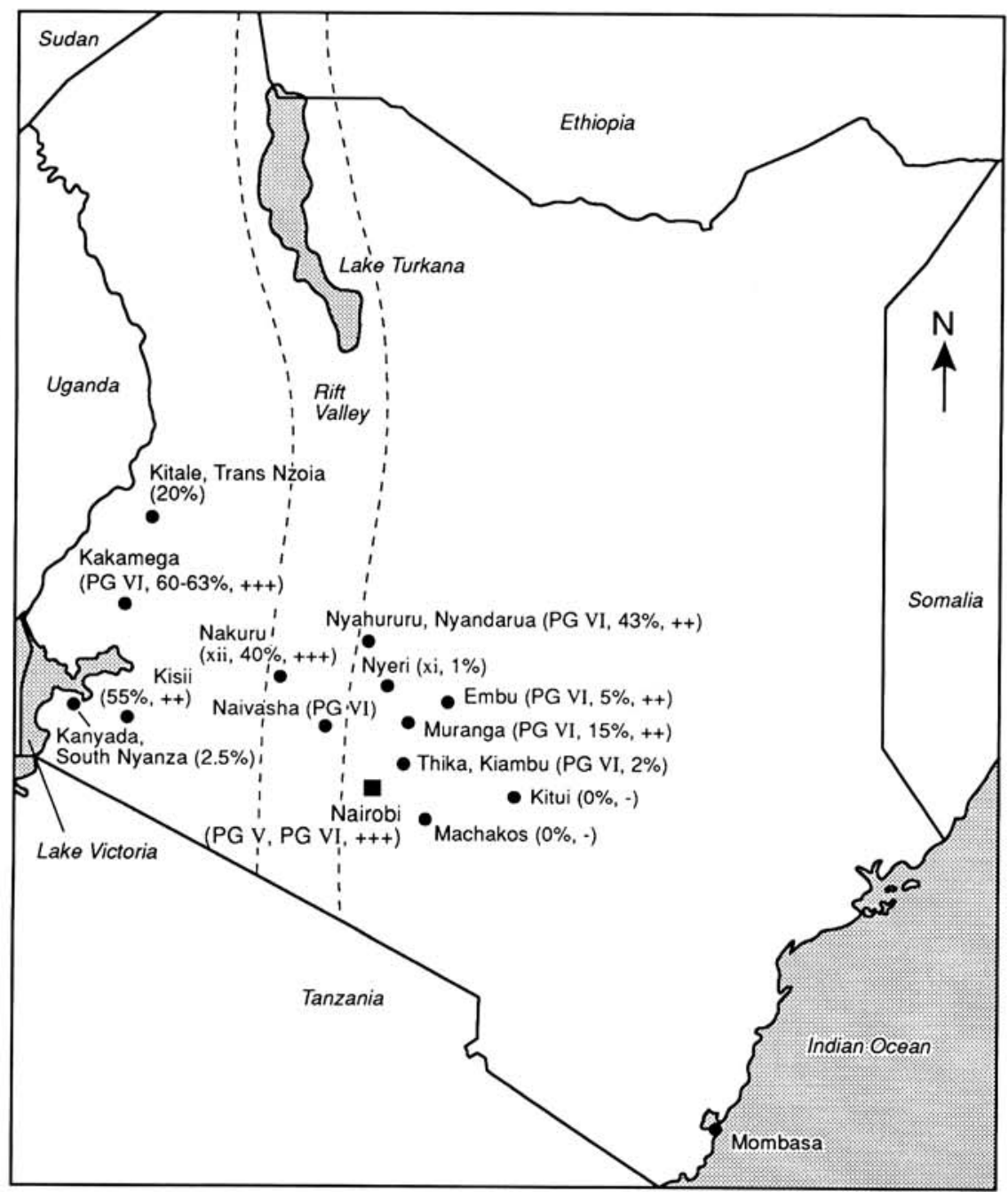

Fig. 1. Geographic distribution of bean common mosaic virus (BCMV) isolates in Kenya during 1981. BCMV pathogenicity groups: PG V (non-necrosis-inducing isolates); PG VI (necrosisinducing isolates); $\mathrm{xi}$ (new group, Amanda-infecting isolate); and xii (new group, non-necrosisinducing isolate). Parameters represent BCMV incidence (\%) and populations of black bean aphid, Aphis fabae. Aphids were characterized using the scale: $-=0 \%$ infestation, $+=1$ to $10 \%$ infestation, $++=11$ to $20 \%$ infestation, $+++=21$ to $50 \%$ infestation, $++++=$ over $51 \%$ infestation. Infestation is percentage of plants with at least one aphid out of approximately 250 plants.
Aphid transmission tests and physical properties of virus isolates. For aphid transmission tests, black bean aphids, $A$. fabae, were cultured on healthy Chinese cabbage, Brassica pekinensis (Lour.) Rupr., in a net cage $(38 \times 45 \times 60 \mathrm{~cm})$ to free them of any virus (4) and then transferred to healthy seedlings of $P$. vulgaris cv. Long Tom in a similar cage. Light was supplied to plants from a white fluorescent lamp located $1 \mathrm{~m}$ above the cage. Groups of 10 aphids were starved for 45 to 60 $\mathrm{min}$, and were then given an acquisition access period of 2 min on BCMV-infected plants of cv. Long Tom before being transferred to healthy plants for an inoculation access period of $20 \mathrm{~min}$.

Crude extracts, prepared by grinding infected leaves in distilled water ( $1: 1 \mathrm{wt} /$ vol), were used to determine dilution end point, thermal inactivation point, and aging in vitro. Inactivation tests were performed by heating sap in a water bath at temperatures ranging from 50 to $70^{\circ} \mathrm{C}$. Sap for aging in vitro was stored between 20 and $25^{\circ} \mathrm{C}$, followed by daily infectivity assays for 1 week on the local host $P$. vulgaris cv. Monroe.

\section{RESULTS}

BCMV distribution, relative abundance of $A$. fabae, and cropping pattern. BCMV was recorded in 18 of 22 locations surveyed. Incidence within fields was high in Western areas (20 to 63\%), generally low at the lake basin, Rift Valley, and Central regions ( 0 to $55 \%$ ), and least in the Eastern areas of Machakos, Kitui, and Embu (0 to 5\%) (Fig. 1). The disease was not observed in four locations at Matinyani, Mutenda (Kitui), Kangundo, and Muta (Machakos) where absence of BCMV coincided with the absence of the vector, Aphis fabae. In most locations, incidence of BCMV was associated with the abundance of A. fabae. Aphis fabae was recorded in large numbers in fields at Ebusarale (Kakamega district), Subukia (Nakuru district), and Nyahururu (Nyandarua district) (data not shown), all areas with high incidence of BCMV.

BCMV was present in bean fields regardless of the cropping system practiced by farmers. In most farms, beans were interplanted with one or more crops, such as maize, potatoes, bananas, cabbage, onions, pyrethrum, avocados, and mangoes. BCMV was observed more frequently in pure bean stands $(83 \%)$ than in beans intercropped with potatoes, cabbage, pyrethrum, or onions (33\%).

Symptomatology and host range. Disease symptoms were the main criteria used for assessing BCMV incidence in the field; invariably, these were typical mosaic associated with stunting and leaf malformation $(5,10)$. Most plant samples that were collected showed these symptoms. A sample from a symptomless plant was collected from each field. Healthy young 
bean seedlings inoculated mechanically with sap from symptomatic tissue produced, in 7 to 10 days, stunted, distorted leaves (Fig. 2) similar to those observed in field-infected plants. Fourteen of 18 virus isolates infected healthy young bean seedlings. Thus, we pursued use of only these 14 virus isolates for further studies. No disease occurred with healthy seedlings inoculated with sap from symptomless plants.

Ten of 36 plant species and cultivars in six families were susceptible to BCMV, but systemic invasion by all 14 virus isolates occurred in only four species: one each in the genera Cassia and Macropithilium, and two in Phaseolus. All the legumes were infected systemically, and most developed mosaic symptoms. The $P$. vulgaris cvs. Canadian Wonder, Rose Coco, Mwezi Moja, and Master Piece exhibited mosaic symptoms associated with leaf malformation and plant stunting; symptoms were often preceded by local discoloration on inoculated primary leaves. Similar mosaic symptoms developed on Garden Contender inoculated with six isolates, whereas plants of this cultivar remained symptomless with the rest of the isolates. Monroe, a local-lesion assay host and bean differential standard for BCMV strains, produced local lesions and nonvascular necrosis extending along the veins; these lesions started as tiny brown spots, which enlarged after 5 to 6 days into rings 2 to 4 $\mathrm{mm}$ in diameter. Red Mexican produced brown lesions when infected with virus strains, but virus was not recovered. $\mathrm{Ca}$ janus cajan produced hypersensitve necrotic lesions after 2 to 3 days with 11 isolates, but severe apical necrosis occurred only with isolates T, K, N, E4, E5, and Nc4. No symptoms occurred with isolates 4 and 10c. Hypersensitive reaction also was observed with Dolichos lablab, but virus was not recovered. Cassia occidentalis reacted to BCMV by producing mosaic that varied from light to deep green but was not severe with isolates 4 and 10c. Macropithilium lathroides was infected by all isolates, producing systemic flecks, followed by mosaic associated with plant

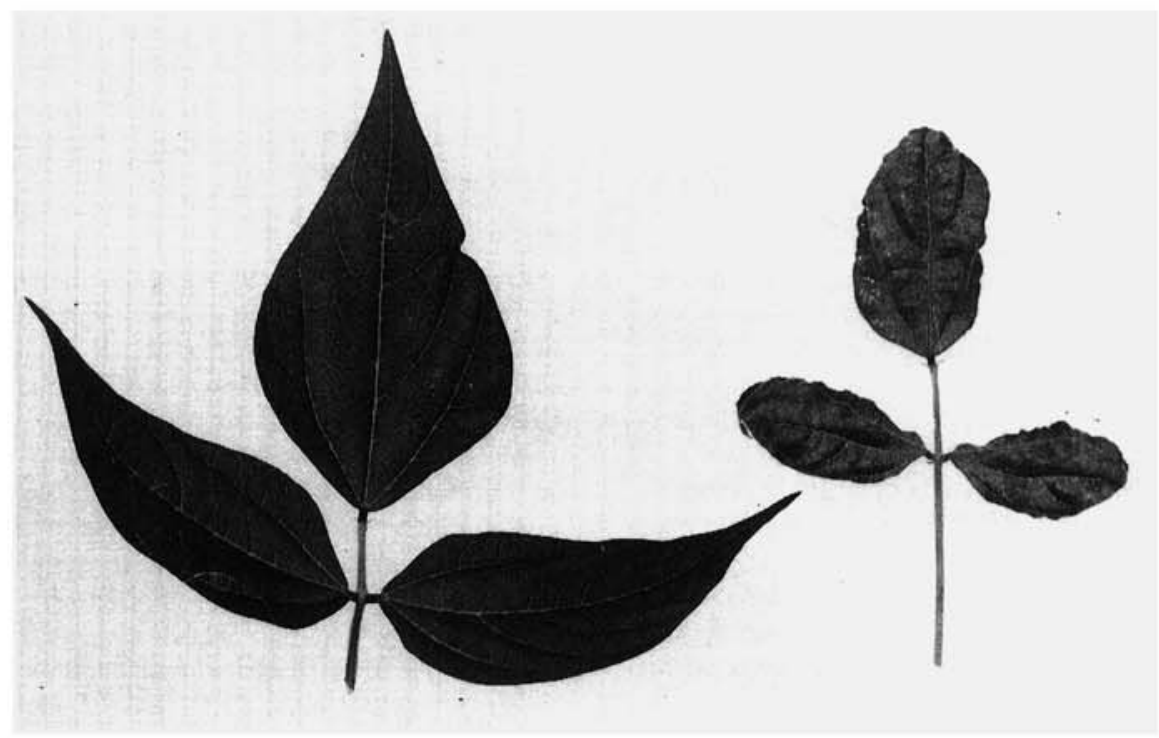

Fig. 2. Healthy leaf of Phaseolus vulgaris cv. Long Tom (left) and diseased leaf (right) showing mosaic and deformation caused by bean common mosaic virus isolate $\mathrm{Nc2}(\mathrm{KN} 3)$.

Table 1. Reactions of bean Phaseolus vulgaris differentials to isolates of bean common mosaic virus (BCMV) from Kenya ${ }^{\mathrm{a}}$

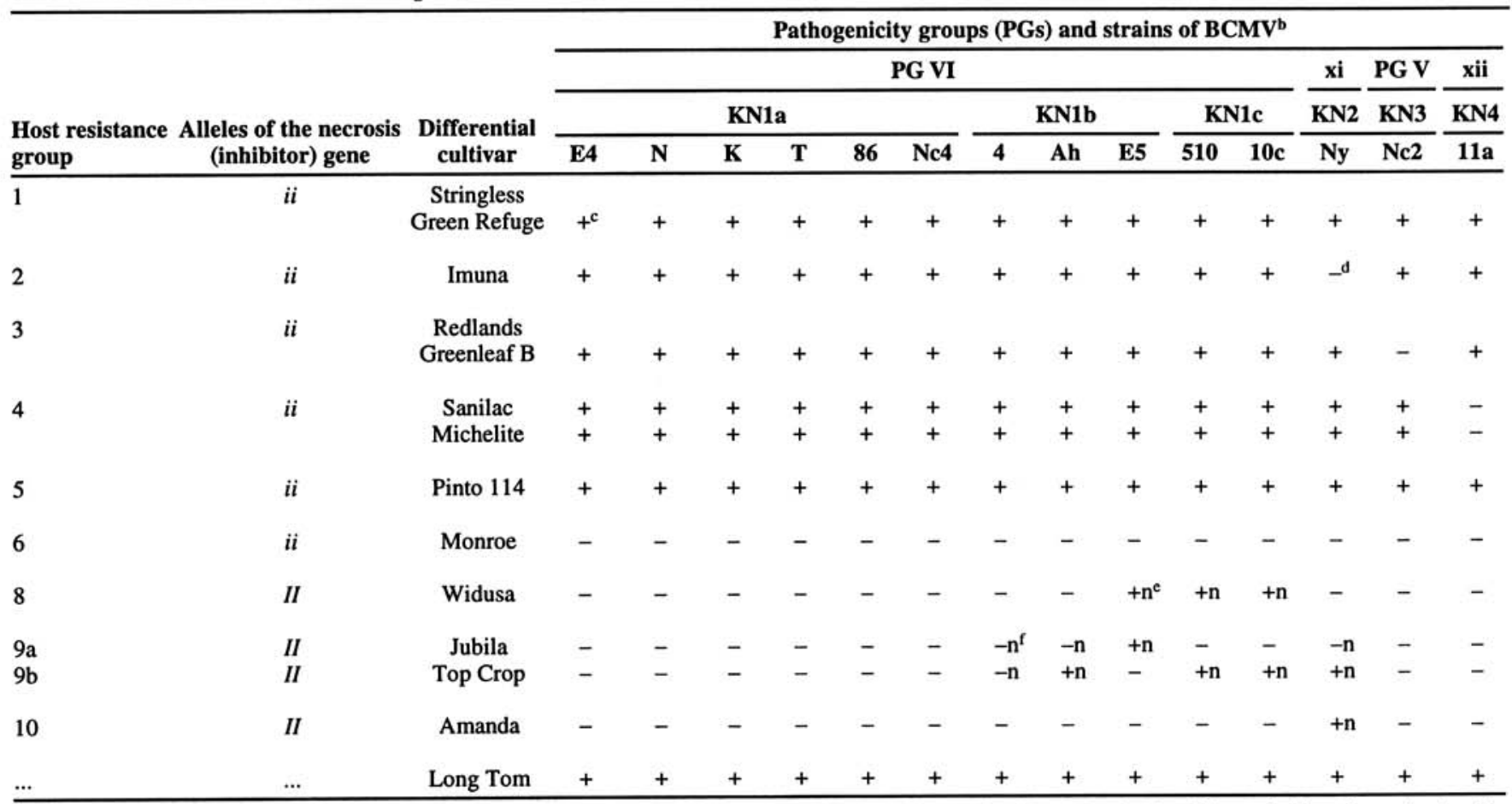

a At least three 12-day-old plants were mechanically inoculated, and one plant was left as a control. Plants were indexed 3 weeks later by using healthy seedlings of the cvs. Long Tom, Dubbele Wittte, or both; the host group and the alleles (...) for the cv. Long Tom are unknown.

${ }^{b}$ xi, xii = new groups.

c Mosaic symptoms, virus recovered by indexing.

d No systemic symptoms, virus not recovered by indexing.

'Systemic necrosis.

${ }^{f}$ Local vein necrosis. 
stunting and leaf rolling. The flecks were more pronounced with $\mathrm{Nc} 2, \mathrm{~N}$, and $10 \mathrm{c}$ than with other isolates. With isolates E4, E5, Nc4, Ah, and Nc2, chlorotic local lesions that developed on Chenopodium album and $C$. amaranticolor expanded into rings after 6 to 9 days.

The following species were not susceptible to BCMV: Amaranthaceae-Amaranthus sp; Chenopodiaceae-Beta vulgaris L., Spinacia annuus L.; Compositae (= Astaraceae)-Helianthus annuus L.; Cucurbitaeae-Cucumis sativa L.; Leguminosae (= Fabaceae)-Cyamopsis tetragonoloba (L.) Taub., Medicago sativa L., Phaseolus calcaratus Roxb. (= Vigna umbelleta (Thumb.) Ohwi \& H. Ohashi), P. lunatus L., $P$. vulgaris cvs. Jamapa and Monel, Pisum sativa L., Trifolium pratense L., Vicia faba L.; SolanaceaeCapsicum annuum L., Datura stramonium L., Lycopersicon esculentum Mill, Nicandra physalodes $(=N$. physaloides $)$ Gaert., Nicotiana tabacum cv. Samsun NN, N. tabacum cv. White burley, and $N$. debynei L.

Aphid transmission and physical properties. BCMV isolates were transmitted from plant to plant by $A$. fabae. Plants were indexed as before on Long Tom, which showed mosaic symptoms characteristic of BCMV. The dilution end points of isolates E4, E5, Nc2, T, 4, Ah, 86, and 11a were similar $\left(10^{-3}\right.$ to $\left.10^{-4}\right) ; \mathrm{N}, \mathrm{K}, \mathrm{Nc} 4$, $10 \mathrm{c}, 510$, and $\mathrm{Ny}$ lost their infectivity when diluted $10^{-4}$ to $10^{-5}$ with distilled water. Infectivity was destroyed after 10 min at $58^{\circ} \mathrm{C}$ with isolates $\mathrm{E} 5, \mathrm{Nc} 2, \mathrm{~N}$, and $\mathrm{K}$, at $56^{\circ} \mathrm{C}$ with $\mathrm{T}, 86$, and $\mathrm{Ny}$, and at $54^{\circ} \mathrm{C}$ with the others. All isolates lost infectivity in vitro within 2 to 4 days at $25^{\circ} \mathrm{C}$.

Differentiation of isolates into PGs. BCMV isolates induced various reactions in standard bean differential cultivars. Usually, mosaic symptoms were produced by the $i i$ gene cultivars, whereas systemic necrosis preceded by local vein necrosis appeared on plants of some cultivars carrying the dominant $I$ gene. None of the uninoculated control plants showed any disease symptoms or evidence of virus systemic infection, an indication that seed was free from virus contamination. On the basis of systemic infection of differential bean cultivars, the $14 \mathrm{BCMV}$ isolates were classed into four PGs that include $\mathrm{V}$ and VI (Table 1).

Eleven isolates belonged to PG VI; they systemically infected all cultivars containing the recessive alleles (ii) of the necrosis gene, except Monroe, which reacted with necrotic rings characteristic of Monroe. Within PG VI, different isolates designated as $\mathrm{KN} 1 \mathrm{a}, \mathrm{KN} 1 \mathrm{~b}$, and $\mathrm{KN} 1 \mathrm{c}$ were further distinguished with respect to reactions of II gene cultivars (Widusa, Jubila, Top Crop, and Amanda). Four of the 11 isolates induced systemic necrosis on one or more of these cultivars, with the exception of Amanda. Of the other PG VI isolates, only isolate 4 induced local vein necrosis; however, the necrosis did not become systemic in either Jubila or Top Crop. Isolate $\mathrm{Ny}$ infected Amanda and Top Crop and also infected all recessive $i$ gene cultivars except Imuna, suggesting that it may be a distinct strain. Similarly, isolate $11 \mathrm{a}$ infected neither any dominant $I$ gene cultivars nor Sanilac or Michelite among the $i i$ gene cultivars. One of the 14 isolates tested, Nc2, belonged to PG V (KN3). Differentiation between this and isolate 11a was based on reactions of Redlands Greenleaf B, and Sanilac or Michelite. The isolates $\mathrm{Ny}$ and $11 \mathrm{a}$, hereafter referred to as $\mathrm{KN} 2$ and $\mathrm{KN} 4$, respectively, represent potentially new groups.

\section{DISCUSSION}

Occurrence of BCMV was recognized by characteristic leaf rolling, vein banding, blistering, distortion, and plant stunting $(2,7,9,12)$. BCMV occurred widely in bean-growing fields in Kenya; incidence varied from 0 to $60 \%$. The variation in virus incidence seemed to be related to the distribution of the aphid vector population, seed selection practices, and the cropping pattern. Aphis fabae was prevalent in farmers' fields during the season and could have caused localized virus transmission $(9,17)$. In farms within Rift Valley and Western Kenya, for example, relatively large populations of $A$. fabae were associated with a virus incidence $>40 \%$. Kulkarni (9), in a survey of viruses affecting East African major food crops, showed that BCMV incidence was related to initial aphid population increase and aphid migration in the region. Results of this study in Kenyan farmers' fields seem to confirm his results. Unsatisfactory seed sorting practices by farmers may have contributed to differences in BCMV incidence because numerous farmers use their own uncertified seed, which may be virus-infected, for planting the next crop.

Bean seed planted in the areas surveyed was obtained from one or more of the following sources: a farmer's own seed (uncertified) from previous harvest, other farmers' seed stocks (uncertified) available at the local market, and certified seed purchased from the Grain Growers Cooperative Unions. Interviews with farmers contacted during the survey revealed that most seed planted originated from farmers' own uncertified stocks from previous harvests. At a farm located at Isukha West in Kakamega, which had $60 \%$ BCMV incidence at a podding stage and a high $A$. fabae population, bean seed originated from the farmer's uncertified stock. At another farm at Gatura (Muranga district), where seed for planting originated from the previous harvest but had been sorted to remove broken, undersized, and discolored seed before planting, BCMV incidence was less than $15 \%$. Virus-infected seed has been shown to serve as a source of virus inoculum for migratory aphid vectors (16). Nev- ertheless, low virus incidence typified most farms in Central and Eastern regions despite relatively high aphid populations. In Central and Eastern Kenya, where bean production is greatest (acreage: Eastern, $40 \%$; Central, $32 \%$; Nyanza, $12 \%$ ), the active seed sorting that precedes planting may be the reason for the low virus incidence.

This study revealed the occurrence of different BCMV strains in Kenya, including necrosis-inducing types. Inoculum prepared from field collections did not infect plant species known to be susceptible to bean yellow mosaic and cowpea aphidborne mosaic viruses, whose symptoms could be confused with those of BCMV $(1,3,7,20)$.

The BCMV isolates could be classed into four PGs. These have been tentatively designated by using the two-letter country code system proposed by Drijfhout (5). The KN1 group isolates, composing $75 \%$ of the isolates analyzed, were infectious to all representative $i i$ gene cultivars upon which they induced mosaic but failed to overcome the resistance in Amanda, indicative of PG VI. These studies confirm previous reports (8) that Kenyan isolates appear similar to the Michelite NL3 group of strains, which are PG VI isolates. Within this group, three isolates were further differentiated by their ability to induce systemic necrosis (temperature-insensitive necrosis). The groups KN2 (able to break the resistance of Amanda) and KN4 (unable to break Michelite resistance) seem to be different and unrelated to the strains previously reported. For example, KN2 induced systemic necrosis (temperature-insensitive necrosis) on Amanda, but failed to infect Imuna, in contrast to reported strains of the PG VI (5). KN3 seems to be a PG V isolate, because of inability to infect Redlands Greenleaf B and all dominant $I$ gene cultivars. Our studies show that BCMV strains widely distributed within Kenya exhibit more variation than obtained by Kulkarni (10) in studies that did not utilize standard bean differential cultivars. The results suggest that resistant selections made at one location in Kenya are unlikely to remain resistant in other areas. Therefore, it is advisable to continue the practice of evaluating beans for resistance to BCMV at different agro-ecological zones in the country.

\section{ACKNOWLEDGMENTS}

The authors thank K. R. Bock for provision of virus isolates and constructively reviewing the manuscript and E. Drijfhout for a supply of standard bean differentials and useful suggestions. We are grateful to John H. Hill, Mark L. Gleason, and Forrest W. Nutter, Jr., for editorial advice and critical review of the manuscript. This paper, which formed part of an M.Sc. thesis submitted to the University of Nairobi by the senior author, is published by permission of the Director, KARI, Nairobi, Kenya.

\section{LITERATURE CITED}

1. Bock, K. R. 1973. East African strains of cowpea aphid-borne mosaic virus. Ann. Appl. Biol. 73:75-83. 
2. Bock, K. R. 1982. The identification and partial characterization of plant viruses in the tropics. Trop. Pest Manage. 28:399-411.

3. Bock, K. R., Guthrie, E. J., Meredith, G. E., and Njuguna, J. M. 1976. Viruses of food legumes. Pages 138-139 in: East African Agriculture and Forestry Research Organization (EAAFRO). Annu. Rep. 1976, Nairobi, Kenya.

4. Buruchara, R. A. 1979 . Identification of a severe strain of bean common mosaic virus isolate from beans Phaseolus vulgaris $\mathrm{L}$. M.Sc. diss. University of Nairobi, Kenya.

5. Drijfhout, E. 1978. Genetic interaction between Phaseolus vulgaris and bean common mosaic virus, with implications for strain identification and breeding for resistance. Cent. Agric. Publ. Doc. Agric. Res. Rep. 872, Wageningen, The Netherlands.

6. Drijfhout, E., Silbernagel, M. J., and Burke, D. W. 1978. Differentiation of strains of bean common mosaic virus. Neth. J. Plant. Pathol. 84:13-26.

7. Galvez, G. E. 1980. Aphid-transmitted viruses. Pages 221-238 in: Bean Production Problems: Disease, Insect, Soil and Climatic Constraints of Phaseolus vulgaris. H. F Schwartz and G. E. Galvez, eds. Centro Internacional de Agricultura Tropical, Cali, Colombia.
8. Kenya Agricultural Research Institute 1980. Pages 192-196 in: Annu. Rep., 1977-80, KARI., Department of Agriculture, Nairobi, Kenya.

9. Kulkarni, H. Y. 1972. A survey of viruses affecting East African major food crops. Ph.D. diss. University of Nairobi, Kenya.

10. Kulkarni, H. Y. 1973. Notes on East African plant virus diseases. IV. Bean common mosaic virus. East Afr. Agric. For. J. 39:72-76.

11. McKern, N. M., Mink, G. I., Barnett, O. W. Mishra, A., Whitaker, L. A., Silbernagel, M. J., Ward, C. W., and Shukla, D. D. 1992. Isolates of bean common mosaic virus comprising two distinct potyviruses. Phytopathology 82:923-929.

12. Morales, F. J., and Bos, L. 1988. Bean common mosaic virus. No. 337 (No. 73 revised) in: Description of Plant Viruses. Association of Applied Biologists, Wellsbourne, England.

13. Omunyin, M. E., Gathuru, E. M., and $\mathrm{Mu}-$ kunya, D. M. 1988. Reactions of cultivars of bean (Phaseolus vulgaris L.) to bean common mosaic virus (BCMV). Trop. Agric. (Trinidad) 65:166-168.

14. Omunyin, M. E., Gathuru, E. M., and Mukunya, D. M. 1988. Effect of bean common mosaic virus on growth and yield of beans. East Afr. Agric. For. J. 54:7-10.
15. Rheenen, H., Van, A., and Muigai, S. G. S. 1984. Control of bean common mosaic by deployment of the dominant $I$ gene. Neth. J. Plant. Pathol. 90: 85-94.

16. Robertson, R. S., Jr. 1962. The role of seed transmission in the epidemiology of bean mosaics in central Washington. Plant Dis. Rep. 42:71-72.

17. Robertson, R. S., Jr., and Klostermeyer, E. C. 1961. Aphid transmission of bean viruses in field beans in Washington. (Abstr.). J. Econ. Entomol. 54:414-416.

18. Silbernagel, M. J. 1969. Mexican strain of bean common mosaic virus. Phytopathology 59:1809-1812.

19. Silbernagel, M. J., Mills, L. J., and Wang, W.Y. 1986. Tanzanian strain of bean common mosaic virus. Plant Dis. 70:839-841.

20. Smith, K. M. 1972. A Textbook of Plant Virus Diseases. Longman Group, London.

21. Vetten, H. J., Lesemann, D.-E., and Maiss, E. 1992. Serotype A and B strains of bean common mosaic virus are two distinct potyviruses. Arch. Virol. (Suppl.) 5:415-431.

22. Wang, W.-Y., Mink, G. I., and Silbernagel, M. J. 1982. Comparison of direct and indirect enzyme-linked immunosorbent assay (ELISA) in the detection of bean common mosaic virus. (Abstr.). Phytopathology 72:954. 